\title{
Minneord om Professor emeritus Kalle Sognnes
}

(1945-2019)

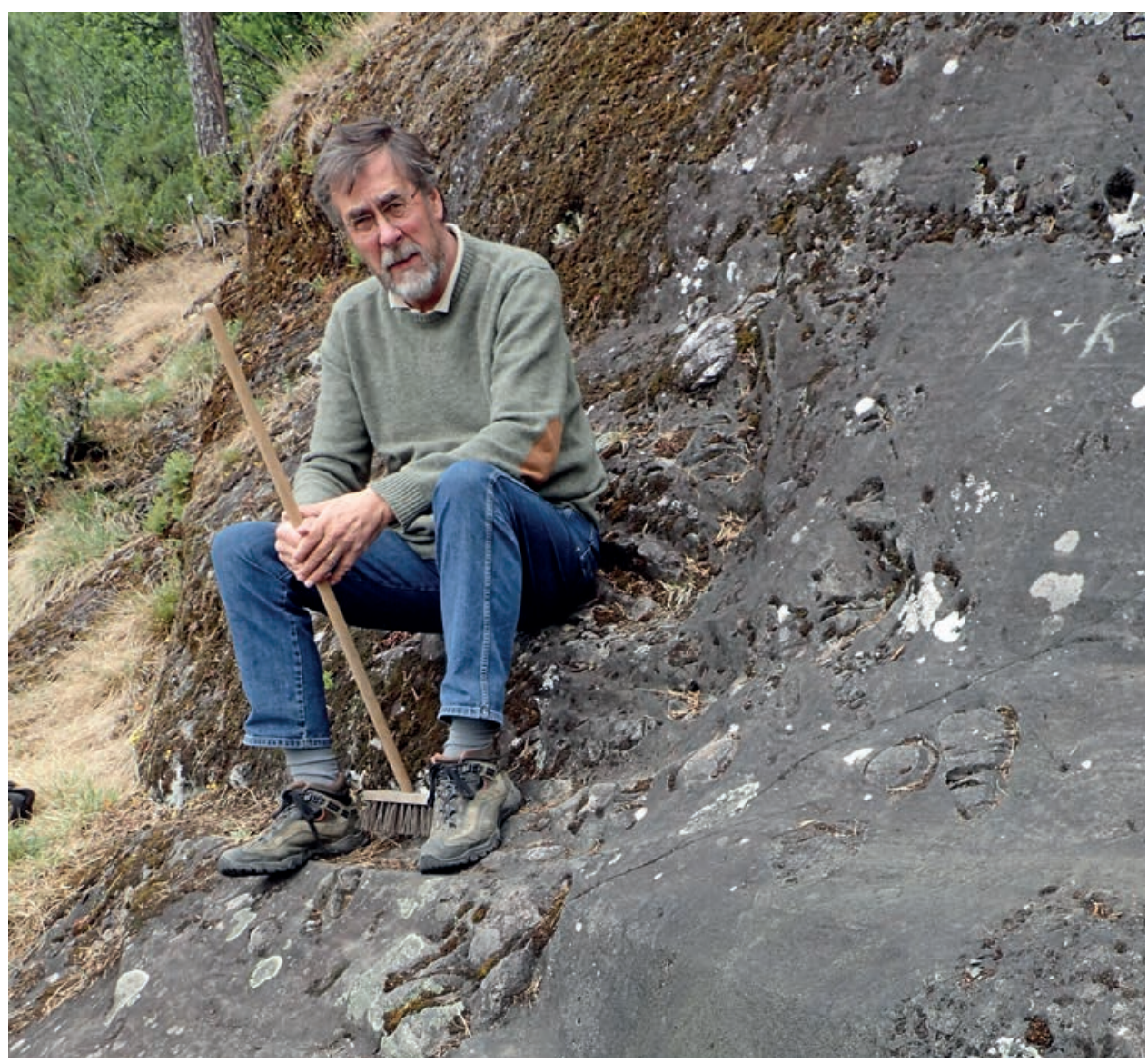

Figur 1. Kalle Sognnes ved Lånkefeltet juni 2018. Foto: H. Stebergløkken. 
29. august 2019 nådde beskjeden ut i det arkeologiske miljøet, om at Professor Emeritus Kalle Sognnes var gått bort. Han ble 73 år gammel. Kondolanser spredte seg raskt, og det var tydelig at sorgen gikk forbi nasjonale grenser. For Kalle har satt sine spor, og hans forskning vil bli stående som sentrale verk, som andre vil dra uendelig nytte av og bygge videre på. Men Kalle som person vil også bli dypt savnet, og er tydelig at han har betydd mye for mange.

Kalle ble født i Bergen i 1945, og avla sin Magistergrad ved Universitetet i Bergen 1973 med tittelen; «Eidfjord i Hardanger: forsøk på analyse av førhistorisk bosetning». I tillegg til arkeologi hadde han også støttefag i geologi og etnografi. Noe han fikk stor nytte av i sitt arbeide. Kalle sine arbeider dekker en lang periode, fra neolitikum til 1800-tallet med vekt på jernalder og middelalder på Vestlandet og Trøndelag i et landskapsperspektiv. Men det er nok allikevel det lange arbeidet innenfor bergkunstforskningen han vil bli husket mest for, og hvor han vil bli stående som en bauta innen sitt fag.

Han ble ansatt ved det som senere ble NTNU i 1976, der han arbeidet frem til pensjonsalderen i 2013. I denne perioden jobbet han både ved Det Kongelige Norske Videnskabers Selskap (DKNVS) - Museet, Vitenskapsmuseet og Institutt for arkeologi og religionsvitenskap. Ved sistnevnte var han leder og nestleder gjennom 10 år. I løpet av sin karriere i Trondheim la han ned et enormt arbeid både i den museale driften, undervisningen og ikke minst forskningen ved arkeologimiljøet her. I tillegg var han en av de sterke kreftene for opprettingen av arkeologiundervisning i Trondheim i 1994. Kalle har også vært bestyrer ved Stjørdal museum Værnes, og nedla et enormt arbeide i opprettelsen av et nytt bergkunstmuseum i Stjørdal.

Formidling og undervisningsarbeid var viktig del av hans arbeid, og en lang rekke arkeologistudenter har fått gleden av å ha Kalle som foreleser. Gjennom hans ekskursjoner til bergkunstfelt fikk en mengde studenter pirret sin nysgjerrighet, som også førte til at mange ønsket å skrive om bergkunst i sin mastergrad, og ha Kalle som veileder. Selv var jeg så heldig å ha han som veileder både gjennom master- og doktorgraden.

Som fersk masterstudent fikk man litt ærefrykt i møte med denne høye mannen med dyp stemme, som øste av sin brede kunnskap. Det tok imidlertid ikke lang tid før man skjønte hvor snill og raus Kalle var. Han delte gladelig av sitt materiale, både upublisert som publisert. Om man stakk hodet innom hans kontor for en kort prat eller et kjapt spørsmål, ble det nesten aldri slik. Selv om Kalle ofte var travel, hadde han nesten alltid tid og ofte ble disse 5 minuttene fort til en halv eller en hel time.

Kalles forskningskarriere viser stor tyngde og bredde. Publiseringslisten rommer over 200 arbeider som vitner om en svært aktiv forsker, og han var aktiv helt frem til det siste. Han har jobbet med ulike tema fra ulike verdensdeler som viser hvor allsidig og kunnskapsrik han var. Publikasjonene viser et høyt faglig nivå, og han var en anerkjent forsker i fagmiljøet. Gjennom de siste 40 årene har han blitt stående som en av de mest sentrale bergkunstforskerne i Norge og Skandinavia, og det er verdt å trekke frem to større verk som omhandler bergkunsten i Midt-Norge; «Prehistoric imagery and landscapes: Rock art in Stjørdal, Trøndelag, Norway» (2001) og «The Northern Rock Art Tradition in Central Norway» (2017). Disse bøkene samler mye av den forskningen som Kalle har gjort av bergkunst i Midt-Norge og vil bli stående som sentrale verk i denne regionen. Vi i miljøet er derfor utrolig takknemlig for at vi kunne gi et festskrift tilbake i anledningen hans 70 årsdag 
i 2015, Ritual Landscapes and Borders wihthin Rock Art Research - Papers in Honour of Professor Kalle Sognnes, med både nasjonale og internasjonale bidrag.

Vel så viktig som å nå frem med sin forskning i det akademiske miljøet, var det også en sentral del av hans forskningsformidling, å gi noe tilbake til lokalsamfunnene. Dette ble jeg oppfordret til å gjøre allerede som masterstudent. Jeg ble fortalt at forskningen er noe som alle skal dra nytte av ikke bare noen akademikere i et forskningsmiljø. Dette ble en viktig lærdom som senere har fulgt meg i min karriere. Kalle var et stort forbilde på denne arenaen, og populærvitenskapelig formidling var noe han prioriterte å gjøre - noe som kommer tydelig frem i hans publiseringsliste. I tillegg holdt han en rekke foredrag ute i lokalsamfunnet, og ikke minst formidlet bergkunstfelt ved nattlysning i det magiske høstmørket. I dag når jeg befinner meg ute i felt og i samtaler med lokale og grunneiere, er det tydelig at lokalsamfunnene kjenner godt til Kalle og hans arbeid.

Kalle var en systematiker av natur, og dette vises også godt $\mathrm{i}$ hans arbeid. Både når det gjelder systematiseringen og arbeidet med bergkunstmaterialet og figurmaterialet. Ved å anvende geografiske modeller i lokalisering av bergkunstfelt, har han kunnet påvise uoppdagede felt i områder med høyt potensiale utfra disse modellene. Dette åpnet opp for å bergkunsten fra et nytt perspektiv, noe som var et litt nedprioritert tema i Trøndelagsregionen før Kalle tok opp denne forskningen. Dokumentasjonsarbeid og utviklingen av bedre metodiske fremgangsmåter er også noe han jobbet mye med, som igjen bidro til bedre forskning.

Jeg tror nok også at Kalle vil bli husket godt for alle sine historier, for han elsket å fortelle historier. Dette var interessante, morsomme og underfundige observeringer han hadde fra sine mange opplevelser. Gjennom disse historiene fikk vi et innblikk i store øyeblikk fra hans karriere og utenlandsopphold både i USA, Mexico og Valcamonica, og ikke minst et lite innblikk i Kalle som familiefar, og de mange reisene hans familie har vært med på. Det er tydelig at familien var viktig for han, og han var også en veldig stolt bestefar. En av de morsomme historiene han delte var et frustrasjonsøyeblikk når det gjaldt tyttebærplukking, for dette var en utfordring for Kalle som var rødgrønn fargeblind. Dette ga han av og til også noen utfordringer når han jobbet med bergmaleriene, men han sa han lærte seg en måte å studere de på.

Han hadde også en egen evne til å se bergkunsten utenfor de normale rammene den ofte «leses» utfra. Dette var også noe han utfordret sine studenter til å gjøre, å bryte opp perspektivene, se sammenhenger på tvers av normale rammer og løfte blikket.

Høsten 2018 var IFRAO (The International Federation of Rock Art Organisations) lagt til Valcamonica. Det ble enda tydeligere hvilket internasjonalt nettverk Kalle hadde da vi kom dit, det var mange gamle kjente han fikk møte igjen der. Vi er flere i bergkunstmiljøet som jeg tror vil sette pris på og minne disse dagene sammen i Valcamonica, med interessante foredrag, majestetisk bergkunst og et glass rødvin på en liten restaurant ved foten av de høye fjellene.

Takk for alle de gode samtalene, Kalle. De har vært mange, og vil bli sterkt savnet. Takk for alle de gode rådene, deling av artikler og materiale, de plutselige hyggelige besøkene på kontoret, oppmuntrende ord når ting har gått i stå og for all den kunnskap du delte. 


\section{Takk}

Gjennom arbeidet med teksten har jeg vært i kontakt med flere av Kalles tidligere kollegaer, takk for disse samtalene, innspill og historier dere har delt. Spesielt takk til professor emeritus Lars F. Stenvik og førsteamanuensis Martin Callanan som har lest og kommentert manuskriptet.

\section{Litteratur}

Stebergløkken, H., Berge, R., Lindgaard, E. og Stuedal, H.V. (eds):

2015 Ritual Landscapes and Borders wihthin Rock Art Research - Papers in Honour of Professor Kalle Sognnes. Oxford: Archaeopress Archaelogy.

Sognnes, K.

1973 Eidfjord i Hardanger: forsøk på analse av førhistorisk bosetning. Magistergradsavhandling $i$ nordisk arkeologi. Universistetet i Bergen.

2001 Prehistoric imagery and landscapes: rock art in Stjørdal, Trøndelag, Norway. BAR international series 998. Oxford: Archaeopress.

2017 The northern rock art tradition in central Norway. BAR International Series 2837. 